\title{
Discovery of drug candidates from some Turkish plants and conservation of biodiversity*
}

\author{
Bilge Şener ${ }^{\ddagger}$ and Ilkay Orhan \\ Department of Pharmacognosy, Faculty of Pharmacy, Gazi University, \\ 06330 Ankara, Turkey
}

\begin{abstract}
Discovery for the advancement of medicine and understanding of life sciences constitutes one of the most powerful ways in which biodiversity can contribute to human society. Bioresources have tremendous potential in providing bioactive compounds for the development of new lead candidates for pharmaceuticals, nutraceuticals, and agrochemicals. Therefore, natural products continue to be an important source of modern drugs in clinical use as an active ingredient, starting material to produce semi-synthetic drugs as well as templates for totally synthetic drugs.

The key to success for discovering therapeutic agents from bioresources is based on bioassay-directed isolation techniques. High-throughput screening tests and mechanismbased screening protocols as well as information of folkloric utilization of plants have led to the discovery of lead compounds as drug candidates. Given the current research and development performance associated with the understanding of disease process, there is still a great need for novel compounds with unique mechanisms of action to treat diseases such as cancer, Alzheimer's disease, arthritis, diabetes, etc. The lecture will highlight bioactive compounds arising from the screening of some Turkish plant extracts.

Due to human population growth and economic pressure, the loss of the earth's biodiversity is one of the most pressing environmental and development issues today. IUPAC-approved recommendations for global cooperation on sustainable utilization and conservation of biodiversity will also be presented as the dissemination effort of the recommendation.
\end{abstract}

\section{INTRODUCTION}

Plants produce a diverse range of structurally novel bioactive molecules, making them a rich source of different types of medicines. Traditional medicines are still the mainstay of about $75-80 \%$ of the world population, mainly in the developing world.

Living organisms are unknown complex mixtures having a potentially large number of secondary metabolites. The most valuable drugs in use have been obtained from bioresources.

Many new natural product-originated bioactive compounds effective in treating several diseases have been isolated from different plants, fungi, and microorganisms. They are unknown complex mixtures having a potentially large number of secondary metabolites. Sensitive bioassays for the highthroughput screening (HTS) methods have been developed to screen these plant extracts. The simplest assays are the ones based on the mechanisms of action of a known drug. The assays have also incorpo-

\footnotetext{
*Paper based on a presentation at the $24^{\text {th }}$ International Symposium on the Chemistry of Natural Products and the $4^{\text {th }}$ International Congress on Biodiversity, held jointly in Delhi, India, 26-31 January 2004. Other presentations are published in this issue, pp. 1-344.

${ }^{\ddagger}$ Corresponding author
} 
rated into efficient testing schemes that are useful to HTS. For example; one assay used for Alzheimer's disease (AD) is based on the inhibition of acetylcholinesterase (AChE). The development of new leads of AChE inhibitors has been realized by Ellman's method for screening of biological sources [1,2].

Our researches have been focused to develop bioactive compounds from Turkish plants as leads for drug candidates. Turkey is one of the richest countries in the world for biological sources depending on different geographical, ecological, and aquatic environments as well as a passageway between Europe, Asia, and Africa. The floristic diversity provides a wide choice of species representing 11000 taxa, of which 3700 are endemic. Turkish flora is the richest of any country in Europe, North Africa, and the Middle East [3]. The results indicated that until the end of 1999, over 930 papers were published reporting the chemical compositions of 830 taxa belonging to 237 genera including 58 families, meaning that only $7.7 \%$ of the flora of Turkey have been investigated chemically. This is almost half of the number determined for the world. It has been estimated that out of ca. 250000 species of flowering plants, only about $15 \%$ have been studied phytochemically [4,5].

During our research activities on the plants growing in Turkey, we found diverse chemical classes of bioactive compounds ranging from simple aromatics (e.g., paeonol) to complex molecules of alkaloids, terpenoids, and steroids showing significant biological activities. Some antiacetylcholinesterase, anti-inflammatory, and antibacterial compounds have been reviewed in this manuscript.

\section{ANTIACETYLCHOLINESTERASE COMPOUNDS}

In our century, acetylcholinesterase inhibitors have become the most popular strategy for increasing cholinergic activity in the brain and have shown the most encouraging results as palliative therapy for AD.

$\mathrm{AD}$ is one of the most common mental problems in the aged population [6-8]. The basal forebrain and brainstem cholinergic systems play also an important role in the regulation of cortical and thalamic electrical activity [9]. The findings from experimental animals, aging, and AD research have provided an experimental foundation for the cholinergic hypothesis of learning and memory [10-12]. Based on the cholinergic hypothesis, AD results from a defect in the cholinergic system. One goal of the treatment for $\mathrm{AD}$ is to increase the acetylcholine level in the brain. Therefore, AChE inhibitors are developed for the treatment of this disease.

$\mathrm{AD}$ is a slowly progressive neuropsychiatric illness principally characterized by memory deficits, it has become the fourth leading cause of death after heart disease, cancer, and stroke in industrialized nations of the United States and Europe. Among the acetylcholinesterase inhibitors used at present, physostigmine and tacrine are not ideal drugs for clinical use due to their low bioavailability, narrow therapeutic window, and some side effects such as hepatotoxicity [13]. More recent drugs like donepezil and rivastigmine have effects only against a mild type of AD. Therefore, the search for novel acetylcholinesterase inhibitors with better properties is necessary.

The acetylcholinesterase catalyzes the hydrolysis of the neurotransmitter acetylcholine, and it has long been an attractive target for rational drug design and development of mechanism-based inhibitors for the treatment of Alzheimer's disease. Therefore, acetylcholinesterase inhibitors are the only class of drugs that produce improvements in cognitive function.

\section{Lycopodium species}

Huperzin A (1) has a special significance among the compounds with acetylcholinesterase inhibitory activity, isolated from natural resources.

Huperzin A $[(5 R, 9 R, 11 E)$-5-amino-11-etilidin-5,6,9,10-tetrahidro-7-metil-5,9-metanosikloocta[b]-piridin-2 $(1 \mathrm{H})$-on], is an alkaloid isolated in 1986 by the researchers of the Shanghai Institute of Materia Medica from the clubmoss Lycopodium serratum Thunb. [syn. Huperzia serrata (Thunb.) 
Trev.] (Lycopodiaceae). This plant, known as "Qing Ceng Ta", has been used in traditional Chinese medicine for its memory-enhancing property for centuries [14].

Over 100 alkaloids, a number of which are the series of huperzin A-R, have been isolated from the genus Lycopodium, which is rich in alkaloid content [15]. Out of them, only huperzin A possesses remarkable acetylcholinesterase inhibitory activity [14].

The activity of huperzin A has been found to be as high as physostigmine, galanthamine, donepezil, and tacrine, the commercial drugs already used against $\mathrm{AD}$, even greater. In various in vivo and ex vivo experiments, it has been shown to inhibit acetylcholinesterase reversibly and also to prevent oxidative cell damage induced by $\beta$-amiloid plaques [16-20].

Related to this subject, our ongoing research on investigation of acetylcholinesterase inhibitory activity of some plants growing in Turkey, we screened five Lycopodium species [L. annotinum L., L. alpinum L., L. clavatum L., L. complanatum subsp. chamaecyparissus A. (Br.) Döll, and L. selago L.] of Lycopodiaceae family regarding their acetylcholinesterase inhibitory activity by using the spectrophotometric method modified by Ellman. Bioassay-guided fractionation of L. clavatum L. extract, which was the only active extract (showed ca. $50 \%$ activity) among the Lycopodium species studied resulted in the isolation of a triterpenoid as the active compound. Its structure was established as $\alpha$-onocerin (2) by spectral techniques. $\alpha$-Onocerin $\left(\mathrm{IC}_{50}=5.2 \mu \mathrm{M}\right)$ inhibited acetylcholinesterase better than donepezil at 1 and $3 \mathrm{mg} / \mathrm{ml}$ concentrations and almost at the same inhibition rate at $5 \mathrm{mg} / \mathrm{ml}$, however, it could not reach the inhibition rates of galanthamine at any dose. $\alpha$-Onocerin showed less inhibition $(37.81 \%)$ at $5 \mathrm{mg} / \mathrm{ml}$ than $3 \mathrm{mg} / \mathrm{ml}(42.06 \%)$, depending on its dose-independent inhibitory activity. The reason could be due to the relationship between enzyme and the binding capacity of the compound in increasing doses. These findings could suggest that $\alpha$-onocerin may be a candidate to prepare chemical derivatives and for structure-activity relationship studies in the treatment of Alzheimer's disease for further research [21].<smiles>C/C=C1/c2[nH]c(=O)ccc2C2(N)/C(=C/C)C(C)CCC12</smiles>

1

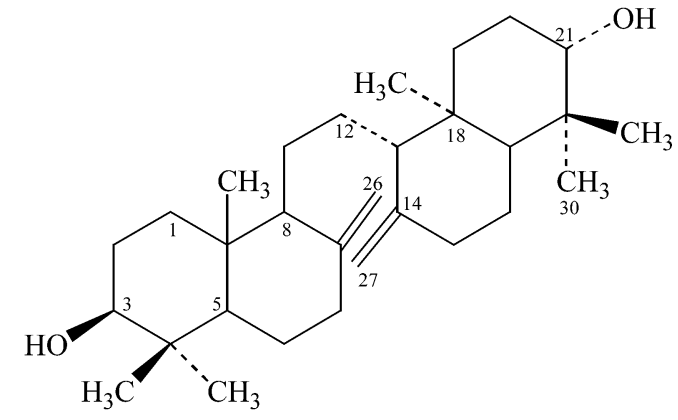

2

\section{Amaryllidaceae alkaloids}

Amaryllidaceae alkaloids are typically found in all species of Amaryllidaceae, which is one of the largest families of ornamental bulbous plants [22]. Amaryllidaceae alkaloids have long held a prominent position in the history of natural products chemistry because of the structural similarity to the essential amino acids phenylalanine and related metabolites of tyrosine [23].

New alkaloids have been isolated from a variety of sources with increasing frequency and characterized using the latest spectroscopic techniques. The medicinal properties of these alkaloids remain of great interest as well as the nature of their structure and stereochemistry. To date, over 190 Amaryllidaceae alkaloids have been isolated. These alkaloids are known to exhibit a variety of biological activities such as antitumor [24,25], antiviral, and anticholinergic activities [26]. Some of them have been used in the treatment of myastenia gravis, myopathy, and diseases of the nervous system. The 
bulbs of Galanthus, Narcissus, and Leucojum have an interest because of their content of galanthamine for the treatment of poliomyelitis.

Galanthamine (3), an alkaloid isolated from some Galanthus species (Amaryllidaceae), has been recently in use in the treatment of $\mathrm{AD}$. It has a reversible action of acetylcholinesterase inhibition and also modulates the nicotinic acetylcholine receptors [27-32]. Although the most common side effect of galanthamine is nausea, it is possible to eliminate nausea by increasing the galanthamine dose slowly [33]. In addition, galanthamine was shown to have no hepatotoxicity [34]. Therefore, galanthamine $\left(\right.$ Nivalin $^{\circledR}$ ) has been approved as its $\mathrm{HBr}$ salt for the first time in Austria, later licensed as Reminyl ${ }^{\circledR}$ in the United States and some European countries, as well as Turkey.

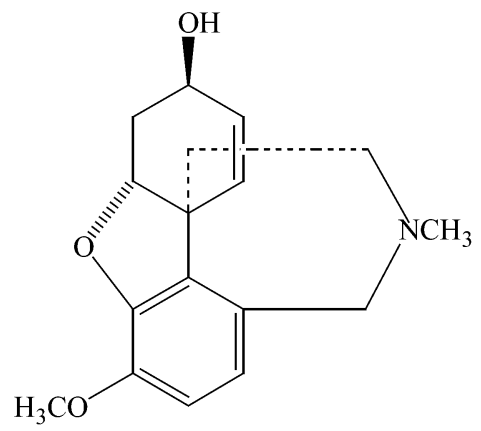

3

Besides, the positive effect of galanthamine was found in several learning and memory tests in animals, based on the cholinergic hypothesis that memory impairments in patients suffering from $A D$ result from a defect in the cholinergic system, and one approach to the treatment for this disease is to enhance the acetylcholine level in the brain [23].

This development has prompted us to investigate the anticholinesterase activity of some plant species of Amaryllidaceae growing in Turkey, namely, Galanthus elwesii Hooker fil., G. ikariae L., Narcissus tazetta subsp. tazetta L., Leucojum aestivum L., and Pancratium maritimum L. by Ellman's method in comparison with galanthamine as the standard drug. The bulbs of some species of Amaryllidaceae cultivated in Turkey have been exported as ornamental plants. In the aforementioned context, we systematically studied the uninvestigated five Amaryllidaceae plants growing in Turkey for their potential anticholinesterase activities [35].

In total, six Amaryllidaceae-type known alkaloids called lycorine (4), tazettine (5), crinine (6), galanthamine (3), 3-epi-hydroxybulbispermine (7), and 2-demethoxymontanine (8) from the active fractions of Galanthus ikariae were obtained by bioactivity-directed fractionation. On the other hand, lycorine, tazettine, 3-epi-hydroxybulbispermine, $\mathrm{N}$-nor-galanthamine (9), and haemantamine (10) were isolated from the active fractions of Narcissus tazetta subsp. tazetta as the common Amaryllidaceae alkaloids. Although G. ikariae and N. tazetta subsp. tazetta extracts showed 75.56 and $46.62 \%$ inhibition, repectively; it made us thought that activity of the extracts being lower than $50 \%$ resulted from the synergistic interaction between the alkaloids isolated. Among these active alkaloids, lycorine $\left(\mathrm{IC}_{50}=3.16 \mu \mathrm{M}\right)$ and galanthamine $\left(\mathrm{IC}_{50}=3.2 \mu \mathrm{M}\right)$ have been determined to exhibit potent inhibitory activity [21].

These findings showed that a single alkaloid is not responsible for anticholinesterase activity of G. ikariae and N. tazetta subsp. tazetta extracts. However, the activity may depend on the synergistic interaction between the alkaloids isolated. According to these results, the bulbs of Amaryllidaceae plants can also be evaluated as a source of anticholinesterase alkaloids in addition to their ornamental properties. 
<smiles>O[C@H]1C=C2CCN3Cc4cc5c(cc4[C@H]([C@H]1O)[C@H]23)OCO5</smiles>

4<smiles>CO[C@H]1C=C[C@]23c4cc5c(cc4COC2(O)CN(C)C3C1)OCO5</smiles>

5<smiles>O[C@@H]1C=C[C@]23CCN(Cc4cc5c(cc42)OCO5)CC3C1</smiles>

6<smiles></smiles><smiles>COc1ccc2c3c1O[C@H]1C[C@H](O)CC[C@]31CNC2</smiles><smiles></smiles>

8<smiles>CO[C@@H]1CN2Cc3cc4c(cc3C13C=C[C@H](O)C3N4C)OCO2</smiles>

In a similar study, Lopez et al. screened 26 extracts prepared from various Narcissus species along with 23 pure Amaryllidaceae-type alkaloids against acetylcholinesterase and suggested that the alkaloids having galanthamine and lycorine skeletons possess inhibitory activity [36].

\section{Isoquinoline alkaloids}

The genus Fumaria L. (Fumarioideae, Papaveraceae) is represented by 19 species in Turkey [37,38]. They are all small annual herbs and known as "Şahtereotu" in Turkey [5]. Some of them are used in folk medicine against eczema, rheumatism, stomach ache, and dysentery. In Anatolia, one of them, Fumaria vaillantii Lois. is widespread where its extracts are used in folk medicine as a blood purifier in the treatment of skin diseases. Fourteen of them have been investigated in terms of molecular diversity in the alkaloidal content and their biological activities [39].

Fumaria species are the invaluable source of isoquinoline alkaloids, many of which possess a wide diversity of molecular structures and biological activities. According to the standard extraction, isolation, and purification procedures described in our previous study [40]; 49 isoquinoline alkaloids have been isolated from 14 Fumaria species [41-56]. All alkaloids were identified on the basis of their extensive spectral data reported in the relevant literatures. Morphological characters used for the description of 13 Fumaria species were also determined [57]. 
Within our project on acetylcholinesterase inhibitors from some Turkish plants, we have also screened Fumaria species from Fumarioideae subfamily (Fumaria asepala Boiss., F. bastardii Bor., F. boissieri Hausskn., F. bracteosa Pomel, F. capreolata L., F. cilicica Hausskn., F. densiflora DC. (syn: F. micrantha Lag.), F. flabellata Gasp., F. gaillardotii Boiss., F. judaica Boiss., F. kralikii Jordan (syn: F. anatolica Boiss.), F. macrocarpa Parlatore, F. microcarpa Boiss. ex Hausskn., F. officinalis L., F. parviflora Lam., F. petteri Reichb. subsp. thuretii (Boiss.) Pugsley (syn: F. thuretii Boiss.), F. pikermiaana Boiss., F. rostellata Knaf, F. schleicheri Soyer-Willement, F. vaillantii Lois. (syn: F. schrammii Valenovsky) for their acetylcholinesterase inhibitory activity by Ellman's method [58].

In the course of our studies on acetylcholinesterase inhibitors [35], the alkaloidal extracts of Fumaria species displayed high inhibitory activity, while galanthamine, the standard drug used in this study, showed $48.80 \pm 0.36 \%$ inhibitory activity. All of the extracts had much higher activity compared to galanthamine, ranging between $84.98 \pm 1.07 \%$ and $96.89 \pm 0.17 \%$ by in vitro using spectrophotometric Ellman's method. Out of these species, $F$. vaillantii, having $94.23 \pm 0.47 \%$ inhibitory activity, was selected for bioactivity-directed fractionation and isolation studies and the common isoquinoline alkaloids named as canadine (11), hydrastine (12), bulbocapnine (13), fumarophycine (14), corydaldine (15), protopine (16), ophiocarpine- $N$-oxide (17), $\beta$-allocryptopine (18), ophiocarpine (19), and berberine (20) were obtained from the active fractions of Fumaria vaillantii. Their acetylcholinesterase inhibitory activities are as follows: Canadine $(56.75 \pm 0.58 \%)$, hydrastine $(10.08 \pm 0.78 \%)$, ophiocarpine $(92.97 \pm 0.45 \%)$, bulbocapnine $(65.23 \pm 0.42 \%)$, fumarophycine $(37.90 \pm 0.99 \%)$, corydaldine $(17.11 \pm 0.89 \%)$, ophiocarpine- $N$-oxide $(81.40 \pm 0.83 \%)$, protopine $(80.53 \pm 0.59 \%)$, $\beta$-allocryptopine $(89.31 \pm 0.41 \%)$, and berberine $(84.97 \pm 0.71 \%)$.

Among the alkaloids, ophiocarpine $\left(\mathrm{IC}_{50}=1.1 \mu \mathrm{M}\right)$ had the most potent inhibitory activity followed by $\beta$-allocryptopine $\left(\mathrm{IC}_{50}=1.3 \mu \mathrm{M}\right)$, berberine $\left(\mathrm{IC}_{50}=1.6 \mu \mathrm{M}\right)$, ophiocarpine- $N$-oxide $\left(\mathrm{IC}_{50}=1.79 \mu \mathrm{M}\right)$, and protopine $\left(\mathrm{IC}_{50}=1.8 \mu \mathrm{M}\right)$. Hydrastine, an alkaloid that has a phthtalideisoquinoline skeleton, and corydaldine, an alkaloid with a dihydroisoquinolone structure, were the least potent alkaloids, leading the suggestion that both types of alkaloids do not have remarkable acetylcholinesterase inhibitory activity. On the other hand, fumarophycine with spirobenzylisoquinoline skeleton and bulbocapnine $\left(\mathrm{IC}_{50}=2.0 \mu \mathrm{M}\right)$ with aporphine skeleton, which have a better $\mathrm{IC}_{50}$ value than galanthamine $\left(\mathrm{IC}_{50}=5.8 \mu \mathrm{M}\right)$, could be considered to contribute to the activity of the extract. Another structure-activity relationship can be established between canadine $\left(\mathrm{IC}_{50}=2.6 \mu \mathrm{M}\right)$ and ophiocarpine $\left(\mathrm{IC}_{50}=1.1 \mu \mathrm{M}\right)$. Both of the alkaloids possess the same tetrahydroprotoberberine structure, except for the lack of a hydroxyl group in canadine. The much higher activity of ophiocarpine than canadine may be based on the existence of this hydroxyl group by increasing the solubility of this compound. Consequently, we conclude that the responsible compounds for the activity of $F$. vaillantii extract were determined as the alkaloids, namely ophiocarpine, $\beta$-allocryptopine, berberine, ophiocarpine- $N$-oxide, and protopine, which have tetrahydroprotoberberine and protoberberine skeletons and the activity may be due to the synergistic interaction between these alkaloids, which may be of therapeutic value in the treatment of $\mathrm{AD}[58]$. 
<smiles>COc1ccc2c(c1OC)CN1CCc3cc4c(cc3C1C2)OCO4</smiles>

11<smiles>COc1ccc2c(c1OC)C(=O)OC2C1c2cc3c(cc2CCN1C)OCO3</smiles>

12<smiles>COc1ccc2c(c1O)-c1c3c(cc4c1C(C2)N(C)CC4)OCO3</smiles>

13<smiles>CCN1c2cc(OC)c(O)cc2C2(Cc3ccc4c(c32)OCO4)C1C(C)=O</smiles>

14<smiles>COc1cc2c(cc1OC)C(=O)NCC2</smiles>

15<smiles>CN1CCc2cc3c(cc2C(=O)Cc2ccc4c(c2C1)OCO4)OCO3</smiles>

16<smiles>COc1ccc2c(c1OC)C[N+]1([O-])CCc3cc4c(cc3C1C2O)OCO4</smiles>

17<smiles>COc1ccc2c(c1OC)CN1CCc3cc4c(cc3C1C2O)OCO4</smiles>

19<smiles>COc1ccc(CC(=O)c2cc3c(cc2CCN(C)C)OCO3)c(OC)c1OC</smiles>

18<smiles></smiles>

20

\section{ANTI-INFLAMMATORY COMPOUNDS}

Both steroidal and nonsteroidal anti-inflammatory drugs currently used in the treatment of inflammatory diseases are known to have various side effects. Thus, investigations for the new anti-inflammatory agents with minimum side effects are still a challenge, and studies on both synthetic drugs and plants are conducted to realize this purpose. In Turkish folk medicine, many plants have been used in the treatment of rheumatoid arthritis and some anti-inflammatory diseases. The aqueous extracts of 29 plant 
species from 18 families were tested for their anti-inflammatory activities by using carrageenan-induced hind paw edema method in mice [59].

\section{Paeonia daurica}

The roots of some Paeonia species (Paeoniaceae) have been used as analgesics, anti-inflammatory agent, antispasmodic, hypotensive, and antiepileptic, especially in East Asian traditional medicinal systems for centuries. In Turkey, there are seven species of Paeonia, however, they are not widely used in folk medicine. In our previous work, the anti-inflammatory activity of two Turkish Paeonia species, $P$. peregrina Miller and P. daurica Andrews, were investigated with carrageenan-induced hind paw edema method in mice, and a significant activity was observed in the roots of $P$. daurica. To isolate the active principle(s), after filtration of the precipitate occurred during the concentration of the ethanolic extract of the roots of $P$. daurica, the remaining extract was subjected to a series of successive fractionations and paeonol (21) was obtained as an active compound [60].

\section{Iris germanica}

Iris germanica L. (Iridaceae) is widely distributed in most parts of the world, and is also cultivated as an ornamental plant. In the preparation of traditional medicines, mainly the rhizomes of this plant are used. Rhizomes of the plant have been used in dropsy and gall bladder diseases as well as antispasmodic, emmenagogue, stimulant, diuretic, and aperient. The juice of the roots of I. germanica is applied to sores and used to remove freckles from the skin. It is employed as an ingredient of composition for purifying blood and for venereal diseases [61].

Human neutrophils are known to be the first line of defense against invading microorganisms. This protection is based on the production of oxidative bursts at the site of microbial invasion. The mechanisms of the site-directed killing of microorganisms and extracellular tumor- and virus-infected cells have been extensively studied. On the other hand, the uncontrolled release of reactive oxygen species (ROS) is suspected to be responsible for certain pathological conditions such as heart attacks, septic shocks, rheumatoid arthritis, and ischemia reperfusion injury [62]. In these cases, the administration of agents that can decrease the neutrophils accumulation in the inflamed area might be a remedy for these conditions.

A cell-based in vitro bioassay was used to examine the anti-inflammatory activity of the rhizomes of Iris germanica L. and to explore their potential as nonsteroidal anti-inflammatory drugs (NSAIDs). The methanolic extract of the rhizomes of Iris germanica of Turkish origin has resulted in the isolation of seven bioactive compounds by a spectrophotometric assay using the activated human neutrophils [63]. The structures of these compounds were identified on the basis of spectroscopic methods and found to be: 5,7-dihydroxy-3-(3'-hydroxy-4',5'dimethoxy)-8-methoxy-4H-1-benzopyran-4-one (22), 5,7-dihydroxy-3-(3'-hydroxy-4',5'-dimethoxy)-6-methoxy-4H-1-benzopyran-4-one (23), 5-hydroxy3-(4'-hydroxy)-6,7-methylene-dioxy-4H-1-benzopyran-4-one (24), 5-methoxy-3-(4'-hydroxy)6,7-methyenedioxy-4H-1-benzopyran-4-one (25), 5,7-dihydroxy-3-(3'-hydroxy-4'-methoxy)6-methoxy-4H-1-benzopyran-4-one (26), 5,7-dihydroxy-3-(3'-methoxy-4'-hydroxy)-6-methoxy$4 H$-1-benzopyran-4-one (27), and isopaeonol (28). 
<smiles>COc1ccc(C(C)=O)c(O)c1</smiles>

21<smiles>COc1cc(-c2coc3c(OC)c(O)cc(O)c3c2=O)cc(O)c1OC</smiles>

22<smiles>COc1cc(-c2coc3cc(O)c(OC)c(O)c3c2=O)cc(O)c1OC</smiles>

23

Compounds $\mathbf{2 3}, \mathbf{2 6}$, and $\mathbf{2 7}$ were found to be the most active among them. Compound $\mathbf{2 8}$ also showed a significant activity, while compounds $\mathbf{2 4}, \mathbf{2 5}$, and $\mathbf{2 6}$ exhibited only low activities when compared with aspirin and indomethacine, clinically used NSAIDs [63].<smiles>O=c1c(-c2ccc(O)cc2)coc2cc3c(c(O)c12)OCO3</smiles>

24<smiles>COc1ccc(-c2coc3cc(O)c(O)c(O)c3c2=O)cc1O</smiles>

26<smiles>COc1c2c(cc3occ(-c4ccc(O)cc4)c(=O)c13)OCO2</smiles>

25<smiles>COc1cc(-c2coc3cc(O)c(OC)c(O)c3c2=O)ccc1O</smiles>

27<smiles>COc1cc(O)ccc1C(C)=O</smiles>

28 


\section{CONCLUSIONS}

Discoveries of lead compounds for the development of new drug candidates from bioresources can help to promote incentives for conservation by providing an economic return to innovative use of those sources.

Screening of natural sources has had an impressive tool of determining active agents. The key to successfully discovering therapeutic agents from bioresources is based on bioassay-directed isolation techniques. HTS tests and mechanism-based screening protocols as well as information of folkloric utilization of plants have led to the discovery of lead compounds as drug candidates.

These results show that the available biodiversity of natural sources and the isolated bioactive compounds may act as potential leads for the development of clinically useful pharmaceuticals. All of the known acetylcholinesterase inhibiting drugs used in therapy of Alzheimer's disease suffer from several side effects such as high toxicity, short duration of biological action, low bioavailability, and narrow therapeutic effects. Consequently, development of new acetylcholinesterase inhibitors with less toxicity and more potent activity are compulsory. The research in finding new drugs with acetylcholinesterase inhibitory activity to be used in the treatment of $\mathrm{AD}$ from natural resources such as huperzin A, also yielded some herbal-originated extracts and/or compounds which act by different mechanisms such as Ginkgo biloba, Panax ginseng, Davilla rugosa, (-)-epigallocatechin, ferulic acid, etc. [19]. However, acetylcholinesterase inhibitors have been accepted to be the most effective in the treatment of $\mathrm{AD}$, so far.

Paeonol, a simple aromatic compound isolated from the roots of Paeonia daurica Andrews, as well as some isoflavonoids obtained from the rhizomes of Iris L. species have a noticeable anti-inflammatory activity when compared with aspirin and indomethacine, clinically used as NSAIDs. These bioactive natural compounds can also serve as models for synthetic compounds in improving the human health. They play valuable leads for nutraceuticals in connection with human nutrition by the general public as well.

Due to human population growth and economic presure, the loss of the earth's biodiveristy is one of the most pressing environmental and development issues today. IUPAC-approved recommendations [64] for global cooperation on sustainable utilization and conservation of biodiversity will also be highlighted as the dissemination effort of the recommendation.

\section{REFERENCES}

1. G. L. Ellman. Arch. Biochem. Biophys. 74, 443 (1958).

2. G. L. Ellman, D. Courtney, V. Andres, R. M. Featherstone. Biochem. Pharmacol. 7, 88 (1961).

3. A. Güner, N. Özhatay, T. Ekim, K. H. C. Başer (Eds.). Flora of Turkey and the East Aegean Islands, Supplement 2, Vol. 11, p. 28, Edinburgh University Press, Edinburgh (2001).

4. K. H. C. Başer. Pure Appl. Chem. 74, 527 (2002).

5. T. Baytop. Therapy with Medicinal Plants in Turkey (Past and Present), $2^{\text {nd }}$ ed., Nobel Medical Presshouse, Istanbul (1999).

6. R. L. Adams, P. L. Craig, O. A. Parsons. Neurolog. Clin. 4, 387 (1984).

7. P. S. Aisen and K. L. Davis. Neurology 48, 35 (1997).

8. S. E. Arnold and A. Kumar. Med. Clin. North Am. 77, 215 (1993).

9. D. L. Bachman, P. A. Wolf, R. T. Linn. Neurology 42, 115 (1992).

10. L. S. Schneider. Clin. Geriatr. Med. 17, 337 (2001).

11. P. Guardado-Santervas. Rev. Neurologia 32, 172 (2001).

12. S. Gauthier. Prog. Neuro-Psycoph. 25, 73 (2001).

13. R. C. Duvoisin. JAMA 206, 1963 (1968).

14. J. S. Liu, Y. L. Zhu, C. M. Yu, Y. Z. Zhou, Y. Y. Han, F. W. Wu, B. F. Qi. Can. J. Chem. 64, 837 (1986). 
15. H. Wang and X. C. Tang. Acta Pharmacol. Sin. 19, 27 (1998).

16. Y. E. Wang, D. X. Yue, X. C. Tang. Acta Pharmacol. Sin. 7, 110 (1986).

17. X. C. Tang. Acta Pharmacol. Sin. 17, 481 (1996).

18. X. C. Tang and Y. F. Han. CNS Drug Rev. 5, 281 (1999).

19. L. Jing, H. Y. Zhang, L. M. Wang, X. C. Tang. Acta Pharmacol. Sin. 20, 141 (1999).

20. J. W. Ye, J. X. Cai, L. M. Wang, X. C. Tang. J. Pharmacol. Exp. Therapeut. 288, 814 (1999).

21. I. Orhan and B. Şener. Chem. Nat. Compds. (Khim. Prir. Soedin.) 39, 383 (2003).

22. S. F. Martin. "The Amaryllidaceae", in The Alkaloids, A. Brossi (Ed.), Vol. 30, p. 251, Academic Press, NewYork (1987).

23. S. Könükol. Pharmacognosic Researches on the Alkaloids of Pancratium maritimum L., Ph.D. thesis, Institute of Health Sciences of Gazi University, Ankara (1992).

24. G. R. Pettit, V. Gaddamidi, D. L. Herald, S. B. Singh, G. M. Cragg, J. M. Schmidt. J. Nat. Prod. 49, 995 (1986).

25. R. K. Y. Zee-Chang, D. A. Berghe, A. J. Vlietinck. J. Med. Chem. 21, 199 (1978).

26. M. Ieven and A. J. Vlietinck. Pharm. Weekbl. 116, 169 (1981).

27. J. R. Boissier, G. Combes, J. Pagny. Ann. Pharm. Franç. 18, 888 (1960).

28. T. Thomsen and H. Kewitz. Life Sci. 46, 1553 (1990).

29. A. Schrattenholz, E. F. R. Pereira, U. Roth, K. H. Weber, E. X. Albuquerrque, A. Maelicke. Mol. Pharmacol. 49, 1 (1996).

30. E. X. Albuquerrque, M. Alkondon, E. F. R. Pereira. J. Pharmacol. Exp. Ther. 280, 1117 (1997).

31. E. D. Levin and B. B. Simon. Psychopharmacol. (Berlin) 138, 217 (1998).

32. P. N. Tariot, P. R. Solomon, J. C. Morris, P. Kershaw, S. Lilienfeld, C. Ding, Galantamine USA10 Study Group. Neurology 54, 2269 (2000).

33. M. A. Raskind, E. R. Peskind, T. Wessel, W. Yuan, Galantamine USA-1 Study Group. Neurology 54, 2261 (2000).

34. C. Guillou, A. Mary, D. Z. Renko, E. Gras, C. Thal. Bioorg. Med. Chem. Lett. 10, 637 (2000).

35. I. Orhan. Investigations on the Acetylcholinesterase Inhibitory Activity of Some Turkish Plants, Ph.D. thesis, Institute of Health Sciences of Gazi University, Ankara (2002).

36. S. Lopez, J. Bastida, F. Viladomat, C. Codina. Life Sci. 71, 2521 (2002).

37. P. H. Davis (Ed.). Flora of Turkey and the East Aegean Islands, Vol. 1, p. 242, Edinburgh University Press, Edinburgh (1965).

38. P. H. Davis, R. R. Mill, K. Tan (Eds.). Flora of Turkey and the East Aegean Islands, Vol. 10, p. 28, Edinburgh University Press, Edinburgh (1988).

39. B. Şener. Acta Pharmaceutica Turcica 44, 205 (2002).

40. B. Şener. Turkish Fumaria L. Species and Their Alkaloids, Associate Professorship thesis, Ankara University, Ankara (1981).

41. G. Blasko, N. Murugesan, F. Hussain, R. Minard, M. Shamma, B. Şener, M. Tanker. Tetrahedron Lett. 22, 3135 (1981).

42. G. Blasko, V. Elango, B. Şener, A. J. Freyer, M. Shamma. J. Org. Chem. 47, 880 (1982).

43. N. Küçükboyacı, F. Bingöl, B. Şener, J. P. Kutney, N. Stoynov. Nat. Prod. Sci. 4, 257 (1998).

44. B. Şener. Int. J. Crude Drug Res. 21, 135 (1983).

45. B. Şener, B. Gözler, R. D. Minard, M. Shamma. Phytochemistry 22, 2073 (1983).

46. B. Şener. Int. J. Crude Drug Res. 22, 79 (1984).

47. B. Şener. Int. J. Crude Drug Res. 22, 45 (1984).

48. B. Şener. Int. J. Crude Drug Res. 22, 181 (1984).

49. B. Şener. Int. J. Crude Drug Res. 22, 185 (1984).

50. B. Şener. J. Nat. Prod. 484, 670 (1985).

51. B. Şener. Int. J. Crude Drug Res. 23, 161 (1985).

52. B. Şener. J. Fac. Pharm. Gazi. 2, 45 (1985).

53. B. Şener. Int. J. Crude Drug Res. 24, 105 (1986). 
54. B. Şener. Int. J. Crude Drug Res. 26, 61 (1988).

55. B. Şener. Pure Appl. Chem. 66, 2295 (1994).

56. B. Şener and H. Temizer. In Bioorganic Chemistry in Healthcare and Technology, U. K. Pandit and F. C. Alderweireldt (Eds.), p. 281 (1991).

57. B. Şener. J. Fac. Pharm. Ankara 12, 83 (1982).

58. B. SSener and I. Orhan. J. Chem. Soc. Pak., March issue, 2003 (in press).

59. E. Yeşilada, A. Mutlugil, B. Şener, E. Sezik. In Proceedings of the $8^{\text {th }}$ Plant Originated Crude Drugs, Cilt II, B. Çubukçu, G. Sarıyar, A. Mat (Eds.), p. 361, Istanbul University Presshouse, Istanbul (1993).

60. E. Yeşilada, A. Mutlugil, B. Şener. Int. J. Pharmacognosy 30, 66 (1992).

61. F. Hanawa, S. Tahara, J. Mizutani. Phytochemistry 30, 157 (1991).

62. D. Bagchi, M. Bagchi, S. J. Stohs. Gen. Pharmacol. 28, 85 (1997).

63. Atta-ur-Rahman, S. Nasim, I. Baig, S. Jalil, I. Orhan, B. Şener, M. I. Choudhary. J. Ethnopharmacol. 86, 177 (2003).

64. A. E. Fischli, U. K. Pandit, D. Stc. Black. Pure Appl. Chem. 74, 697 (2002). 